\title{
Clinico-pathological Analysis of Cervical Pap Smear in Patients Attending Gynecology OPD of a Medical College
}

\author{
Renuka Tamrakar ${ }^{1 *}$, Sabin Ranabhat ${ }^{2}$, Madhu Shrestha ${ }^{3}$, Sandesh Poudel ${ }^{3}$, Sabita Shrestha ${ }^{1}$, Bandana \\ Khanal' ${ }^{1}$, Rakshya Joshi', Basant Sharma ${ }^{1}$, Dhan Khatri', Janak Lamichhane ${ }^{1}$
}

\section{Author Info:}

'Department of Obstetrics and Gynecology, Chitwan Medical College, Bharatpur, Nepal

2Department of Pathology, Chitwan Medical College, Bharatpur, Nepal

3Paropakar Maternity and Women's Hospital, Kathmandu, Nepal.

\section{Corresponding Author:}

Dr. Renuka Tamrakar,

Department of Obstetrics and Gynecology, Chitwan Medical College Teaching Hospital, Bharatpur, Nepal.

Email/Contact: tamrakarenuka@gmail.com

\begin{abstract}
Background: Cervical cancer ranks the most common cancer among Nepalese women. Cervical and vaginal infections constitute the most common gynecological problems. Through Pap smear screening, early diagnosis, follow up and treatment, morbidity and mortality can be reduced by $70 \%$ and $80 \%$ respectively.
\end{abstract}

Methods: This retrospective study was conducted to know the incidence of abnormal cervical epithelial lesions and cervico-vaginal infections. It was carried out in the Outpatient Department of Gynecology at Chitwan Medical College from April 2018 to March 2019. The data were collected and standard statistical analysis done using Microsoft Excel 2007.

Results: The most prevalent cervical epithelial cell abnormality was atypical squamous cells of undetermined significance (3.43\%) whereas the least common was low grade squamous intraepithelial lesion $(0.21 \%)$. The most prevalent cervical vaginal infection was Bacterial vaginosis (12.30\%) whereas the least prevalent was Trichomoniasis $(0.29 \%)$. The majority of the women with epithelial cell abnormality were in the age group of 31-40 years whereas the lowest number in the age group less than 20 years. The highest prevalence of cervical vaginal infection was in the reproductive age group (31-50 years) and the lowest in the age above 51 years. Most of the patients had multiple symptoms like vaginal discharge, genital itching, whereas only (20.17\%) visited for routine screening.

Conclusion: Atypical squamous cells of undetermined significance and Bacterial vaginosis were the most common findings in Pap smear test representing abnormal cytology of cervix and cervicovaginal infection respectively.

Keywords: ASCUS; Bacterial vaginosis; Candidiasis; Cervico-vaginal infection; LSIL; HSIL; Trichomoniasis

QR Code
How to cite this article in Vancouver Style?




\section{INTRODUCTION}

Worldwide, cervical cancer is the fourth leading cause of morbidity and mortality in patients. Seventy percent of it occurs in developing countries.1,2 Cervical cancer ranks as the most common cancer among Nepalese women between 15 to 44 years of age. ${ }^{3,4}$ Cervical cancer is also the leading cause of death in Nepalese women., ${ }^{5,6}$ Fortunately, through periodic screening, early diagnosis, follow up and treatment, morbidity and mortality can be reduced by $70 \%$ and $80 \%$ respectively. ${ }^{7}$

Cervical cancer is preventable and curable cancer as precancerous cells are found at an early stage. ${ }^{8}$ According to $\mathrm{WHO}$, main strategy for reducing the incidence of cervical cancer is through increasing awareness of women about cervical Pap smear screening. ${ }^{9}$ Screening techniques such as conventional Pap smear and or Liquid based Pap smear cytology, VIA, VILI, and HC2 are being used to screen and detect cervical cancer in precancerous stage. ${ }^{10}$ According to Alliance of cervical cancer prevention, the Pap smear test is very specific but moderately sensitive ${ }^{11}$ and has become a standard screening test. Bethesda System is used for reporting the result. Apart from abnormal cervical epithelial lesions, cervical-vaginal infections can also be diagnosed by cervical Pap smear.

Gardnerella vaginalis, Candidiasis and Trichomoniasis are responsible for $90 \%$ of cases of cervical-vaginal infections. ${ }^{12}$ In general, cervical and vaginal infections are significantly associated with morbidity, complications and high cost of treatment..$^{13}$ The aim of our study was to determine the prevalence of abnormal cervical epithelial lesions and cervical-vaginal infections in cervical Pap smear specimens.

This retrospective study was done to know the incidence of abnormal cervical lesions in cervical Pap smear specimens, as well as to find out the most prevalent pathogens in the vagina and cervix in women who attended the Outpatient Department of Obstetrics and Gynecology in Chitwan Medical College.

\section{MATERIALS AND METHODS}

Samples were collected from all the patients who had Pap smear screening from April 2018 to March 2019. All the women who were sexually active were included and women who had Per vaginum bleeding were excluded from the study.

The Pap smear samples were collected after proper counselling and informed consent was taken from the patient attending OPD with and without problems. Ethical approval from CMC-IRC was taken in July 2020. Cervical Pap smear reporting was done according to Bethesda System by the pathologists. Data were analyzed by using Microsoft Excel 2007.

\section{RESULTS}

The out patient department (OPD) register of CMC Hospital from 14 April 2018 to 13 March 2019 showed that a total of 25,729 patients received services.

In this one-year period, 1388 Pap smear samples were taken which accounted for $5.39 \%$ of patients. Forty-seven samples were reported inadequate or unsatisfactory (3.38\%). So, a total of 1341 samples were analysed.

A total of 1280 samples were reported normal whereas 61 samples (4.54\%) had some form of intraepithelial abnormalities. Among those 61 abnormal smears, most (75.41\%) had atypical squamous cells of undetermined significance (ASCUS), 12 had (19.67\%) high grade intraepithelial lesion (HSIL), whereas only 3 had $(4.92 \%)$ low grade intraepithelial lesion (LSIL). These account for $4.39 \%$ of total Pap smear samples (Table 1).

\section{Table 1: Abnormal Pap smear result}

$\begin{array}{ll}\text { Diagnosis } & \text { Total number (\%) } \\ \text { ASCUS } & 46(3.43) \\ \text { LSIL } & 3(0.21) \\ \text { HSIL } & 12(0.89) \\ \text { SCC } & 0\end{array}$

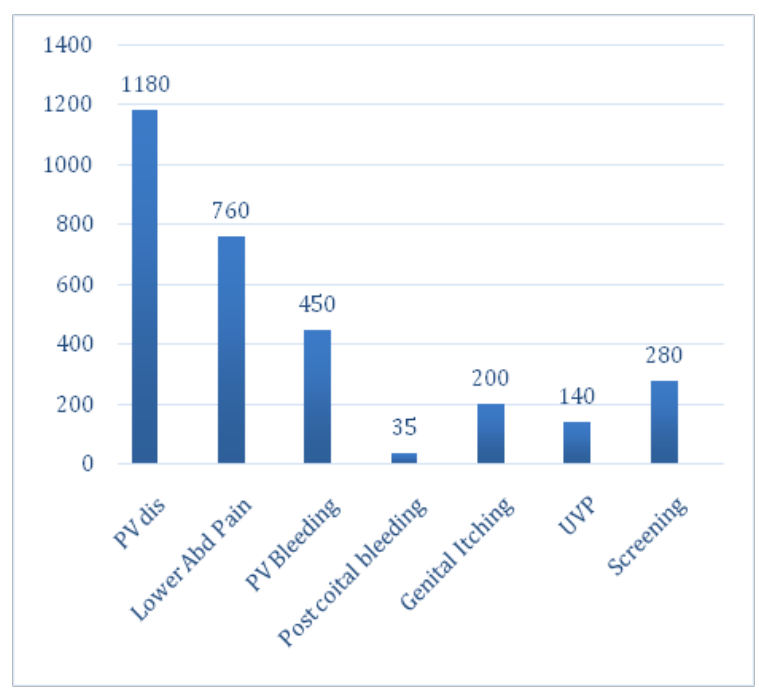

Figure 1: Distribution of Symptoms 
Table 2: Age distribution

$\begin{array}{lc}\text { Age } & \text { Number of patients } \\ <20 \text { years } & 20(1.44 \%) \\ 21-30 \text { years } & 245(17.58 \%) \\ 31-40 \text { years } & 537(38.69 \%) \\ 41-50 \text { years } & 386(27.80 \%) \\ 51-60 \text { years } & 139(10.01 \%) \\ >60 \text { years } & 62(4.47 \%)\end{array}$

These samples were further sent for cervical biopsies and histological evaluations.

The highest number of patients 1062 (76.51\%) having abnormal epithelial abnormalities was in the age-group of 31 to 60 years with mean of 43.34 years (Table 3 ).

\begin{tabular}{lcll}
\multicolumn{4}{l}{ Table 3: Distribution of specific vaginal organisms } \\
Age & BV & CA & TV \\
$<20$ years & 3 & 0 & 0 \\
$21-30$ years & 32 & 4 & 1 \\
$31-40$ years & 62 & 13 & 2 \\
$41-50$ years & 52 & 8 & 0 \\
$51-60$ years & 12 & 0 & 0 \\
$>60$ years & 4 & 0 & 0
\end{tabular}

*Bacterial vaginosis ** Candida albicans

*** Trichomonasis vaginalis

Inflammation was the next common Pap smear findings. Among 227 inflammatory smears, 193 patients had (14.39\%) specific cervical-vaginal infection: Bacterial vaginosis 165 cases (12.30\%), Candidiasis 25 cases (1.78\%) and Trichomoniasis 3 cases $(0.29 \%)$. Most common cervical vaginal infection was due to Bacterial vaginosis $(12.30 \%)$ (Table 4). The highest prevalence of cervical vaginal infection was also seen in the reproductive age group (31-50 years) and the lowest was in the age above 51 years (Table 3 ).

Regarding the clinical presentation, 1180 patients had PV discharge (85.01\%), 760 patients had lower abdomen pain (54.75\%), 200 patients had genital itching (14.40\%), 450 patients had abnormal or irregular PV bleeding (32.42\%), 35 patients had post coital bleeding (2.52\%) and 140 patients had uterovaginal prolapse (UVP) (10.10\%). Most of the patients had multiple symptoms whereas only 280 (20.17\%) had routine screening without any genital symptoms (Figure 1).

\section{DISCUSSION}

Cervical cancer, though is the second most common malignancy in gynecology patients, is preventable as it undergoes a long pre-invasive stage. ${ }^{13,14}$ Cervical Pap smear cytology has become the standard cancer screening tool for detection of cervical pathology..$^{15}$ It is well known that on average it takes approximately 10 years for CIN II, III lesion to progress to an invasive cancer. ${ }^{16}$

During a period of one year, 1388 smears were studied. Among which 47 samples were unsatisfactory (3.38\%). This was almost equal to the studies done by Bamanikar et al, Ranabhat et al, Sarma et al, Alta et al, Laxmi et al, Vaghela et al and Ramu et al, 8,17-22 in which unsatisfactory smears were $(5.7 \%, 3.12 \%, 6.6 \%, 6.31 \%, 4.36 \%, 4.8 \%$ and $2.01 \%)$ respectively. However, this number is much less than the study done by Patel et al (8.9\%)23, so the total 1341 samples were studied.

In this study, the prevalence of abnormal epithelial lesion was found to be $4.54 \%$ which includes atypical squamous cells of undetermined significance (ASCUS), low grade intraepithelial lesion (LSIL) and high-grade intraepithelial lesion (HSIL). Studies had shown that the prevalence of epithelial cell abnormalities were different in different studies done by Ranabhat et al, Laxmi et al, Ramu et al Tailor et al, Saha et al, Renuka et al, Nair et al, Selhi et al and Verma et al respectively $(1.7 \%, 4.45 \%, 1.4 \%, 1.89 \%, 10.3 \%, 1.8 \%, 5.6 \%, 2.0 \%$ and $13.6 \%) .17,20,22,25-29$ The percentage of epithelial cell abnormalities was $2.3 \%$ to $6.6 \%$ in United States, $1.87 \%$ to $5.9 \%$ in India and $1.6 \%$ to $7.9 \%$ in Middle East. ${ }^{30}$ This may be due to lack of awareness and education of Pap smear. As these days, women are more educated and come for screening or consultation and treatment with or without any symptoms. But this awareness is only limited in the urban areas.

Our study determines 1280 cases (97.41\%) of negative for intraepithelial lesion or malignancy (NILM) with normal Pap smears, non-specific inflammation and infections like Bacterial vaginosis, Candida albicans and Trichomonas vaginalis. This result almost corresponds to the study done by Ranabhat et al. ${ }^{17}$ Laxmi et al. ${ }^{20}$ and Tailor et al. ${ }^{24}$ where it was found to be $98.29 \%, 95.53 \%$ and $98.10 \%$ respectively. Whereas the studies done by Vaghela et al, Ramu et al and Saha et al, NILM were $47 \%, 35.88 \%$ and $50.6 \%$ respectively, which is lower than our study. ${ }^{21,22,25}$

Our study revealed ASCUS (3.43\%) to be the most common epithelial cell abnormality. This is similar to many other studies where the most common epithelial cell abnormality was ASCUS. ${ }^{31}$ This result may be due to the screening at the earliest period, as ASCUS is the very initial stage. It progresses to LSIL, HSIL and Squamous cell carcinoma (SCC). The 
precursor lesions occur 5-10 years to progress to an invasive cancer. However, the study done by Tailor et al, the incidence of ASCUS was $40.74 \%$, which was quite high in comparison to other studies. ${ }^{24}$ Severe form of disease process like HSIL was found to be $(0.89 \%)$. Squamous cell carcinoma was not noted in our study.

The age range was 23-60 years and the mean age was 43.34 years with the epithelial cell abnormality, similar findings were detected by other studies. ${ }^{17,20,24}$ In our study LSIL and HSIL were $0.22 \%$ and $0.89 \%$ respectively but it was very high (17\% and $12 \%)$ in the study done by Joshi et al. ${ }^{32}$

In our study, the mean age of the study population was 41.11 years. Maximum numbers of cases 530 (38.18\%) were in between the age group of 31-40 years which was similar to the other studies..$^{20,23,33-35}$ This could be due to early marriage and higher sexual activity in married women. Although cases ranged from 14 to 80 years of age, those women who were more than 65 years old had a history of abnormal uterine bleeding and uterovaginal prolapse.

Patients who underwent pap smear had or did not have symptoms like lower abdomen pain, PV discharge, genital itching, PV bleeding, post coital bleeding and uterovaginal prolapse. Among those with positive epithelial abnormality, $85 \%$ had vaginal discharge, $55 \%$ had lower abdomen pain, $15 \%$ had genital itching and $20 \%$ had come for screening. These similar findings were also noted in the studies done by Bamanikar et al and Laxmi et al. 8,20

In our study, $14.39 \%$ of patients had cervicalvaginal infection with one of the microorganisms such as Bacterial vaginosis, Candida vaginalis and Trichomonas vaginalis. The highest rate of cervicalvaginal infection was due to Bacterial vaginosis. The prevalence of cervical-vaginal infections was mostly found in the age group 21-50 years and lowest rate was noted in the age group above 50 years.

In the study done by Adad et al, the frequency of Candida, Gardnerella and Trichomonas was (22.5\%, $15.9 \%, 3.4 \%$ ) respectively. ${ }^{11}$ Possibly, the frequency of different infections is related to living standard, hygiene habits and awareness of the population. In the 21st century there has been a decrease in the frequency of cervical-vaginal infection by Trichomonas vaginalis and an increase in the frequency of Candida species.

In our study, Bacterial vaginosis (12.30\%) was the most common cervical-vaginal infection. Other studies by Ranabhat et al., Vaghela et al., Ramu et al., Saha et al., Renuka et al., and Verma et al. revealed $7.6 \%, 1.6 \%, 0.72 \%, 7.1 \%, 5.4 \%$ and $8.8 \%$ cases of Bacterial vaginosis respectively. ${ }^{17,21,22,25,26,29}$

The prevalence of Candida Albicans was 1.86\%. Studies had shown that the prevalence of Candida were different in different studies done by Ranabhat et al., Ramu et al., and Tailor et al., respectively (1\%, $3.71 \%$ and $0.45 \%) .{ }^{17,22,24}$

Trichomonas vaginalis was detected in $0.22 \%$ cases, which is in contrast to other studies where there were $0.36 \%, 0.77 \%, 3.2 \%$ and $0.6 \%$ cases respectively. $22,24,25,28$ In general, all the infections were most frequent in the age group 21-50 years. Therefore, Pap smear screening should be done immediately after the females are sexually active irrespective of age and marriage. It should be kept under routine examination. Pap smear should be made available at the basic health care centre.

Our study focuses on the importance of Pap smear screening for the detection of not only abnormal cervical epithelial lesions but also the cervical-vaginal pathogens Gardnerella vaginalis, Candidiasis and Trichomoniasis infections. In our study the prevalence of abnormal epithelial lesions is equal to the prevalence found in other South Asian nations.

The prevalence of cervical-vaginal infections was more than the prevalence found in other South Asian nations. Bacterial vaginosis was found to be the most common cervical-vaginal infection.

\section{CONCLUSION}

Atypical squamous cells of undetermined significance is the most commonly reported cytologic abnormality which may be related with certain types of HPV and yeast infection, inflammation, low hormonal level or benign growth. Hence, more testing like HPV test or another Pap test may be needed.

In addition, the pap smear test may be used in screening of Bacterial vaginosis eliminating the need for further vaginal sampling collection.

\section{REFERENCES}

1. Bray F, Ferlay J, Soerjomataram I, Siegel RL, Torre LA, Jemal A. Global cancer statistics 2018: GLOBOCAN estimates of incidence and mortatily worldwide for 36 cancers in 185 countries. CA Cancer J Clin. 2018;68:394-424. https://doi.org/10.3322/caac.21492 
2. Tamrakar SR, Chawla CD. A Clinical Audit of Pap Smear Test for Screening of Cervical Cancer. NJOG. 2012;7(2):21-4. https://doi.org/10.3126/ njog.v7i2.11137

3. Family Health Division (FDH). National Guideline for Cervical Cancer Screening and Prevention in Nepal [Internet]. 2011 [cited 18 Aug 2020]. Available from: http://whonepal.healthrepository.org/ bitstream/123456789/498/1/National\%20 Guideline\%20for\%20CCSP.pdf

4. ICO Information Centre on HPV and Cancer. Nepal Human Papillomavirus and Related Cancers Fact Sheet 2017 [Internet]. 2017 [cited 18 Aug 2020]. Available from: http://hpvcentre. net/statistic/reports/NPL_FS.pdf

5. National Cancer Registry Program. Hospital based cancer registry 10 years consolidated report (2003-2012) [Internet]. 2015[cited 18 Aug 2020]. Available from: http://www.bpkihs. edu/

6. National Cancer Registry Program. Report of hospital-based cancer registry 2015 [Internet]. 2015 [cited 21 January 2020] Available: www. bpkmch.org.np.

7. Vijaya LP, SreeGouri SR. Study and Analysis of Two Hundred Cervical PAP Smears in Our Hospital. Int J of Contemporary Med Res. 2016;3(9):2787-9. https://www.ijcmr.com/ uploads/7/7/4/6/77464738/ijcmr_939_v1_ sep_22_1_3.pdf

8. Bamanikar SA, Chandanwale SS, Baravkar DS, Dapkekar P. Study of Cervical Pap Smears in a Tertiary Hospital. Indian Medical Gazette. 2014;148(7):250-4.

9. World Health Organization (WHO) (2017). Strategic framework for the comprehensive control of cancer cervix in South- East Asia Region [Internet]. 2015 [cited 18 Aug 2020]. Available from: http://apps.who.int/iris/bitstr eam/10665/152098/1/9789290224723-MRH .pdf.

10. Dhakal S. Oncoprevention in gynecology. JNMA J Nepal Med Assoc. 2010;49(178):16773. https://doi.org/10.31729/jnma.126

11. Alliance for cervical cancer prevention. Pap smear: An important but imperfect screening method. http://screening.iarc.fr/doc/Rh_pap_ smears.pdf. (2020/8/18)

12. Adad SJ, De Lima RV, Sawan ZT, Silva ML, De
Souza MA, et al. Frequency of Trichomonas vaginalis, Candida sp and Gardnerella vaginalis in cervical -vaginal smears in four different decades. Sao Paulo Med J. 2001;119:200$205 . \quad$ https://doi.org/10.1590/S151631802001000600004

13. Heller DS, Pitsos M, Skurnick J. Does the presence of vaginitis on a Pap smear correlate with clinical symptoms in the patient? J Reprod Med. 2008;53:429-34. https://pubmed.ncbi. nlm.nih.gov/18664061/

14. Ramadevi E MN, Madhavi G B, Sudha Rani V, Padmalatha R, Shamili G. A study of correlation between cytology and histopathology with colposcopic findings. Int J Intg Med Sci. 2017;4:477-83. https://doi.org/10.16965/ ijims.2017.105

15. Rathod GB SD. Histopathological vs Cytological Findings in Cervical Lesions (Bethesda System) A Comparative Study. IAM. 2015;2(8):136. https://iaimjournal.com/wp-content/ uploads/2015/08/iaim_2015_0208_02.pdf

16. 16. Wright TC. Cervical Cancer Screening in the 21st Century: is it Time to Retire the PAP Smear? Clin Obstet Gynecol. 2007;50(2):313-23. https:// doi.org/10.1097/GRF.0b013e31804a8285

17. 17. Ranabhat SK, Shrestha R, Tiwari M. Analysis of Abnormal Epithelial Lesions in Cervical Pap Smears in Mid- Western Nepal. Journal of Pathology of Nepal. 2011;1:30-33. DOI:

18. https://doi.org/10.3126/jpn.v1i1.4447

19. 18. Sarma U, Mahanta J, Talukdar K. Pattern of Abnormal Cervical Cytology in Women Attending Tertiary Hospital. Int J Sci Res Pub. 2012;2(12):1-4. http://www.ijsrp.org/researchpaper-1212/ijsrp-p1256.pdf

20. 19. Alta BL, Prasad U, Shamili M, S. Satish kumar. Cytological Patterns of Cervical Pap Smears with Histopathological Correlation. Int J Res Med Sci. 2015;3(8):1911-1961. DOI: https://doi. org/10.18203/2320-6012.jjrms20150300

21. 20. Laxmi RC, Shrestha P, Pradhan B. Analysis of Cervical Cancer Screening at Patan Hospital Nepal. JCMC. 2018;8(23):1-4. https://doi. org/10.3126/jcmc.v8i1.23707

22. 21. Vaghela BK, Vaghela VK, Santawani PM. Analysis of Abnormal Cervical Cytology in Papanicolaou Smears at Tertiary Care CenterA Retrospective Study. IJBAR. 2014;5(1):47-9. https://doi.org/10.7439/ijbar.v5i1.55 
23. 22. Ramu S, Bindu BJ, Murthy N. Pap Smear as Early Diagnostic Tool for Cervical Cancer- A Life Saviour. Trop J Path Micro. 2018;4(1):22-6. https://doi.org/10.17511/jopm.2018.i01.04

24. 23. Patel $C B$, Shah $P C$, Bhagat VM. A Role of Cervical Pap Smear as a Screening Tool in Diagnosis of Lesions of Cervix-AOne-yearStudy. International Journal of Medical Science and Public Health. 2016 Sept 1;5(9):1841-5. https:// doi.org/10.5455/ijmsph.2016.30122015340

25. 24. Tailor HJ, Patel RD, Patel PR, Bhagat VM. Study of Cervical Pap Smear in a Tertiary Care Hospital of South Gujarat, India. Int J Res Med Sci. 2016 Jan;4(1):286-288. https://doi. org/10.18203/2320-6012.jjrms20160044

26. 25. Saha K, Sengupta M, Mistry CJ. Cytological findings of Conventional Cervical Papanicolaou Smear in a Tertiary Care Hospital. Global Research Analysis. 2013;2:149-151. https://doi. org/10.15373/22778160

27. Renuka N, Sultana A. Cytopathological Study of Cervical Smear: A Hospital Based Retrospective Study. Medical Journal of Islamic World Academy of Sciences. 2014;22(1):42-9. https:// doi.org/10.12816/0008170

28. Nair RV, Shwetha BR, Manju A, Solanke PV. Papanicolaou (Pap) Test Screening in a Tertiary Care Teaching Hospital in South India. IJMSCI. 2015;2(8):1260-5. https://doi.org/10.18535/ ijmsci/v2i8.07

29. Selhi PK, Singh A, Kaur H, Sood N. Trends in Cervical Cytology of Conventional Pap Smears According to Revised Bethesda System; A Study of 638 cases. IJRRMS. 2014 Jan-March;4(1):16-20. https://www. semanticscholar.org/paper/Trends-in-cervicalcytology-of-conveno-nal-smears-A-Selhi-Sing h/4533818f9f4001d7603fc9ce654f254d74939 $\mathrm{aOf}$

30. Verma I, Jain V, Kaur T. Application of Bethesda System for Cervical Cytology in Unhealthy Cervix. J Clin Diagn Res. 2014 Sept;8(9):26-30. https://doi.org/10.7860/JCDR/2014/9620.4893

31. Mulay k, Swain M, Patra S, Gowrishankar S. A Comparative Study of Cervical Smears in an Urban Hospital in India and a Populationbased Screening Program in Mauritius. Indian Journal of Pathology and Microbiology. 2009 Jan 1;52(1):34-37. PMID: 19136776; https://doi. org/10.4103/0377-4929.44959

32. Saslow D, Solomon D, Lawson HW, Killackey
M, Kulasingam S, Cain et al. American Cancer Society, American Society for Colposcopy and Cervical Pathology, and American Society for Clinical Pathology Screening Guidelines for the Prevention and Early Detection of Cervical Cancer. Journal of Lower Genital Tract Disease. 2012;16(3):175-204. https://doi.org/10.1097/ LGT.0b013e31824ca9d5

33. Joshi PK C, Thakur N. Correlation of Pap Smear and Colposcopy in Relation to Histopathological Findings in Detection of Premalignant Lesions of Cervix in a Tertiary Care Centre. International J of Scientific Study. 2015;3:55-60. https://www. ijss-sn.com/uploads/2/0/1/5/20153321/ijss_ nov_oa13.pdf

34. Dhakal R, Makaju R, Sharma S, Bhandari S, Shrestha S, Bastakoti R. Correlation of Cervical Pap Smear with Biopsy in the Lesion of Cervix. Kathmandu Univ med J. 2016;14:254-257. https://pubmed.ncbi.nlm.nih.gov/28814689/

35. Biocea A, Patrascu A, Surlin V, Iliescu L, Schenker M, Chiutu L. Correlations between Colposcopy and Histologic Results from Colposcopically Directed Biopsy in Cervical Precancerous Lesions. Rom J Morphol Embryol. 2012;53:735741. PMID: 23188433

36. Mainali N, Homagai N, Nepal N, Choudhary P. A Correlation Study of Cervical Cytology on Pap Smear with Cervical Biopsy in Tertiary Hospital of Eastern Nepal. J Pathol Nep. 2018;8:13891392. https://doi.org/10.3126/jpn.v8i2.20993 